\title{
Familial Scheuermann disease
}

INSERM

\section{Source}

INSERM. (1999). Orphanet: an online rare disease and orphan drug data base. Familial Scheuermann disease. ORPHA:3135

Familial Scheuermann disease is characterized by kyphotic deformity of the spine that develops in adolescence. The spinal deformity includes irregularities of the vertebral endplates, the presence of Schmorl's nodes, disk-space narrowing, and vertebral wedging and is diagnosed using lateral radiographs of the spine. The thoracic spine is most often affected, but the lumbar spine may also be involved. Analysis of the mode of inheritance in a sample of 90 pedigrees derived from the Siberian population supported an autosomal dominant mode of inheritance with complete penetrance in boys and incomplete penetrance in girls. 